\title{
HANKISS ELEMÉR MINT RENITENS ÚJHISTORIKUS
}

\section{ELEMÉR HANKISS: A RECALCITRANT NEW HISTORICIST}

\author{
Z. Karvalics László \\ docens, történész, Szegedi Tudományegyetem, a kőszegi Felsőbbfokú Tanulmányok Intézete ösztöndijasa \\ info@iask.hu
}

\begin{abstract}
ÖSSZEFOGLALÁS
Írásom fő célja, hogy a néhai Hankiss Elemér számára helyet találjak valamiféle diszciplináris térben. A vaskos köteteiben (Az emberi kaland, A befejezetlen ember) alkalmazott módszer, mindennapi életünk rejtélyeinek a boncolgatása és a kompozíciós jellemzők a Stephen Greenblatt műveiben megjelenő „új historizmus” felé vitték. Kitérőkkel tarkított magyarázatom, amelynek során egy fogpiszkálótartó kalandos történetét ecsetelem, épp ezt a Hankiss-módszert igyekszik megvilágítani: végy egy apró tárgyat (például egy sótartót), és mutasd meg, milyen mély értelmű üzenetek hordozója. Igyekszem megmutatni, hogy egyenes út vezet az irodalmi művek komplexitás-problémáin és hatásán töprengő ifjú Hankisstól a civilizációelméletét a szabadság labirintusa köré építő idős Hankisshoz.
\end{abstract}

\section{ABSTRACT}

The main goal of this paper is to find a disciplinary assignment for the late Elemér Hankiss. The method, the hidden assumptions, and the compositional features of the exposition in his voluminous books (The Human Adventure and The Unfinished Man) propelled him to the direction of new historicism, represented by Stephen Greenblatt's works. My roundabout reasoning highlights Hankiss's method to use small objects (like a salt shaker) as holders of deep messages with odd and peculiar admixtures from the history of toothpicks and toothpick holders. I try to demonstrate, that there is a direct link between the young Hankiss, coping with complexity problems and influences of literature, and the late Hankiss, who builds his civilization theory around the maze of freedom.

Kulcsszavak: Hankiss, Kőszeg, új historizmus, elméletek, emberi kaland

Keywords: Hankiss, Kőszeg, new historicism, theories, human adventure

Töltőtoll, gemkapocs, cipzár, könyvespolc, villa, ezüst étkészlet vagy tapadócsíkos üzenőcetli (Post-it)? Amikor Henry Petroski, a Duke University technikatörténésze fejezeteket vagy monográfiákat komponál mindennapi környezetünk 
banálisnak tűnő, aprócska tárgyainak történetéről (Petroski, 1994), elsősorban a mérnöki géniusz érdekli. A dizájn, a tervezés folyamata, a próbálkozások, de fóleg a mélyen emberi hibák és kudarcok (Petroski, 1982) szerepe abban, ahogyan aztán mégis egyre több hasznos tárgyacska evolúcióját kísérhetjük szemmel. Eközben nem feledkezik meg azokról a gazdasági és kulturális változásokról sem, amelyeket a mind elterjedtebb használatra vagy épp a tömeggyártásra való átállásra vezethetünk vissza. Petroski - megérdemelt díjesővel fogadott - históriai rekonstrukcióinak izgalmas adatvilága mögött azonban mindig ott lebeg valamennyi spiritualitás is. Amihez csak nyúl, abban a tökéletlenségben és a korlátosságban rejlő hajtóerők jeleit azonosítja - mindazt, amit Koch Sándor a „létezés alapjának" tekintve dicsér (Koch et al., 1989).

Hankiss Elemért más foglalkoztatja: az artefaktumok, a teremtett tárgyak transzcendenciája, amellyel az emberi élmények mélyszerkezetéből hoznak üzenetet kettős szerepükkel és természetükkel. „A tárgyak [...] megnyitnak olyan életlehetőségeket, amelyek egyébként el vannak zárva elölünk”, miközben „tulajdonként" korlátot is jelentenek, föleg a mértéktelen vagy túlzó ragaszkodás miatt, amellyel egyéb dolgokat kiszorítva szükítik annak a terét, ami másképp „megélhető" volna (Hankiss, 1997). A kettősség mindkét oldalán valójában a szabadság problémája áll, ami az „emberi létezés” alapja és talán legfontosabb instanciája, annak sokatmondó „befejezetlenségével” együtt. Nem véletlen, hogy a szabadság fogalom nyirkos útvesztőibe és elegáns kiállítótermeibe is szinte bárhonnan beszaladhatunk, mint Forrest Gump szélsodorta madártolla (Hankiss, 2014). Elég ehhez a véletlen és az emberi akarat összefonódott terében akár egy labdába is szabadság-generátort belelátni, vagy (egy különösen emlékezetes példával) a sótartóban felfedezni ,,a szabadság ujjongó élményét” (Hankiss, 2014), amit a felfelé igyekvő barokk tornyokra emlékeztető formai nekilendülések és megtorpanások közvetítenek.

Az érett Hankiss nagy összegző műveinek (Hankiss, 2014) olvasói az ilyen és ehhez hasonló jelentéskapcsolatok teremtésének számtalan variációjával szembesülnek: hol érdekességként, hol sokatmondó illusztrációként, hol revelatív összefüggésekhez vezető felismerések forrásaként. A következőkben amellett érvelek, hogy e sajátos alkotói pozíció mögött nem pusztán a briliáns népszerüsítő esszéstílust érdemes azonosítani, s a hankissi kompozícióteremtés nem „intézhető el” műveltségmorzsák látványos egymás mellé rendezéseként vagy késői „filozófiai fordulatának" szükségszerü következményeként sem. Amivel Hankiss tusakodik, az egyrészt nagyon is beágyazható kortárs társadalomelméleti narratívákba, másrészt szerves kapcsolat van az évtizedekkel korábbi Hankiss strukturalizmusból és rendszerelméletből építkező dilemmái és összegzőnek szánt, civilizációelméleti bevezetésként újra- és újraformált gondolkodói korpuszai között.

De induljunk el mi is egy aprócska tárgytól. Vegyük kézbe minden idők egyik legelegánsabb, legnagyobb példányszámban gyártott és fennmaradt porcelán 
fogpiszkálótartóját, a Lefton 6436-ost. Egy magyar immigráns amerikai közönség számára, Japánban gyártott kultusztermékét a második világháború utáni évekből. Mert futhatott plusz aranycsík a prémium-változatok talpa körül, lehetett fehérebb a porcelánalap és élénkebbek a rápingált virágminták a 2898-ason, üzenhetett letisztultságot a zöld mintájával a 02876-os, s büvölhette el a 671-esek enyhe sárga, kék vagy rózsaszín alapszíne és matt tapintása az ínyenceket - valahogy mégis a 6436-osban érezzük ragyogni az időtlen tökéletesség, vagy inkább eltaláltság visszfényét.

Mindazok, akik már találkoztak a Kárpát-medencében leginkább elterjedt, fekvő porcelán fogpiszkálótartók példányaival, amelyek (gyakran Patent márkajelzéssel) a Bécs melletti Währing gyárából kerültek forgalomba, gyönyörködés közben sajátos otthonosság érzetet fedezhetnek fel magukban. Szinte minden ugyanolyan a Lefton 6436-oson, a méret, a külön „egybetalp”, a színek, a virágminta: az egyetlen feltünő különbség az, hogy a Leftonok gömbölydedek: egyetlen vonalat vagy szögletet nem találunk rajtuk. Az aljuk ovális és nem tégla alakú. A két szélük is ívben lekerekedik. A rés, amelyen benyúlva kiemeljük a fa fogvájót, szintén minden pontján hajlított (és aranyozott is). Csak találgatásokra szorítkozhatunk azzal kapcsolatban, hogy vajon minek köszönhető a 6436-os morfológiájában egyidejüleg megjelenő otthonosság és idegenség. A szlovákok, mint a magyarok; a cseheknél ellenben már gömbölyödésnek-öblösödésnek indulnak a formák, ám az egybetalp helyett négy aprócska lábon állnak a fogpiszkálótartók. Bajorföldön minden sokkal szögletesebb, a meisseni terméktervezők pedig keskenyebbre és karcsúbbra szabták a maguk darabjait, emiatt azok sokkal magasabbra is emelkednek. S ha azt gondolnánk, hogy a jellegzetes közép-európai alapforma a nagy amerikai olvasztótégelyben a sokkal szabálytalanabb vonalvezetésü, fegyelmezetlen, túldíszített francia rokontárgyak hatására vált cizelláltabbá, rafináltabbá, nem is tévedhetnénk nagyobbat. A 6436-os ugyanis nem más, mint egy korábbi, nagyon sikeres termék egyszerü utánzata.

Az 1894-es amerikai tarifatörvénynek köszönhetően sokkal olcsóbb lett a díszített porcelántárgyak bevitele, s megnyílt az út az európai export felfutásához. Reinhold Schlegelmilch két (a türingiai, Erfurthoz közeli Suhl városában és a felső-sziléziai Tillowitzban alapított, s jóval olcsóbban müködő) gyárából meg is indult az egy idő után R. S. Prussia márkanevet viselö áruk dömpingje. Ezek között az asztali porcelántárgyak között találjuk a 6436-os elődjét, amelytől egyszerủen megkülönböztethetetlen volna a Leftoné, ha az aljában nem lenne ott a gyári jelzés. Annyit tudhatunk tehát, hogy a korábban a divatruhaüzletben érintett, a vészkorszak elől 1938-ban Amerikába emigráló, Chicagóban 1939-ben letelepedő, saját cégét 1941-ben elindító Lefton Zoltán György jó érzékkel utazott 1945ben Japánba, hogy ottani termelőkapacitásokra építve sok-sok egyéb, márkás porcelántermék mellett egy, az USA-ban már évtizedek óta ismert és használt német fogpiszkálótartó „,utángyártásába” is fogjon. Ezzel amúgy nem volt egyedül: az 
R. S. Prussia olyan hírnevet szerzett magának, hogy fénykorában, 1910 körül számos amerikai és japán cég másolta már a termékeit. (Így az sem lehetetlen, hogy a megoldást nem Leftonnál, hanem a japán cégpartnereknél kell keresni.)

Egyetlen tárgy mögött máris emberek, sorsok és gyárak összegabalyodott világába zuhanunk. George Zoltan Leftonéba (1905-1996), aki cége elindulása után további tizenkét rokonát menekítette ki Amerikába, és adott nekik munkát a gyárában. Találkozása ifjúkori szerelmével, Magdával, New Yorkban, akitől az emigrációs útvonalaik különbözősége és a lány szigorú családja szakította el, hogy aztán mindketten felbontsák előző házasságukat, és életük végéig egymás mellett maradjanak. Vagy itt van a még furcsább Schlegelmilch-történet. Az R. S. Prussia porcelánok önálló gyüjtőközössége nagy meglepetéssel értesült róla, hogy Suhlban nem egy, hanem két Schlegelmilch-gyár müködött. Csakhogy (mint azt egy 1984-es szakdolgozatból kinövő kutatás kiderítette) Reinhold és Erdmann Schlegelmilch két különböző porcelánüzemet vitt, s a névazonosságon kívül semmiféle rokoni kapcsolat nem volt köztük. A Suhlba 1899-ben, Langenwiesenből áttelepülő gyárat még néhai Leonhard Schlegelmilch alapította, az ő Julius fia költöztette tovább, és Erdmann igazgatta.

Ha azt a gazdaságtörténeti epizódot mutattuk volna be részletesen, ahogyan egy brazíliai utazás hatására Charles Forster hozzáfog a libatollat kiszorító olcsó fa fogvájók tömeggyártásához a 19. század utolsó harmadában, földrengésszerü változásokat indítva el az ellátási láncokban és a fogyasztói szokásokban, bizonyára sokakban felidézett volna egy másik, sokkal ismertebbé lett epizódot, majd félezer évvel korábbról. Azt az utazást, amelynek során Poggio Bracciolini 1417ben egy német kolostorban felleli Lucretius De rerum naturájának egy kéziratát, lemásolja, kiadja, s evvel - legalábbis Stephen Greenblatt (2015) szerint - döntő lökést ad a modern természettudományos gondolkodás kialakulásának, új életre keltve a szekularizálódásnak induló világkép irányába forduló szellemi erővonalak talán legfontosabbikát, végső soron világra segítve a reneszánsznak nevezett páratlan kultúrtörténeti időszakot. S noha abban Greenblattnek, az újhistorikus irányzat legismertebb képviselőjének kétségkívül igaza van, hogy Poggio Bracciolini személyes „stratégiái” és cselekvése nélkül nem vagy nem abban az időpontban kerül bele Lucretius műve a gondolkodás megpezsdülő véráramába, de a kézirat hatását minden bizonnyal túlbecsüli: az epikureus gondolat e kézirat nélkül is számos hajszáléren keresztül befolyásolta már a diskurzusképzést és a világmodell-alkotást, s Lucretius recepciója a reneszánszhoz vezető számos lökéshullámnak csak egyike volt.

Ám azt, hogy a nagy, átfogó változások jól visszavezethetőek kisebb események, folyamatok, emberek és dolgok különös és speciális együttállására, középpontba emelte az irodalomtudományból indult, de később kulturális materializmusnak vagy történeti antropológiának is nevezett új historizmus (New Historicism) lassan negyedszázados irányzata. Ez „többnyire az irodalom és az anyagi világ 
kölcsönös »áramlását« (circulation) kutatja”, axiómának tekintve, hogy „minden megnyilvánulás beágyazódik az anyagi tevékenységek rendszerébe" (Dobos, 2001). Az újhistorikus nézőpont olyan társadalomtudományi irály, amelynek révén - a Greenblattet idéző Lábadi Zsombor (2002) szerint - „a történelem nem változatlan struktúrákban ragadható meg, körvonalai elmosódottak, és folyamatos átalakulásban vannak. A dolgok rendje nem egyértelmüen meghatározott...” Ám a kényszerü búcsú ,az objektivitás, a teljesség, a hiteles rekonstrukció értékeitől” (Dobos, 2001) nem béklyóba ver, hanem a korlátozottság felismerésének és elfogadásának révén új értelmet ad, új módszerekhez vezet, új narrációk lehetőségét kínálja, nagy alkotói szabadsággal, a komor és komoly társadalomtörténeti színpadra visszacsempészett játékossággal és korábban érvénytelenként elutasított levezetéstípusok újraélesztésével. Epizodikus történetszilánkok, anekdoták, narráció-középpontba állított periferikus tárgyak „látszólag partikuláris történéseket vizsgálnak és visznek színre, melyek - egészen más szempontból - reprezentatívak, és képesek megragadni a történelmi társadalom szövetében megbúvó szimbolikus cselekvéseket" (Kiss, 2006), hogy a következő pillanatban ideiglenes tudásunk már-már szilárdnak hitt építményén egy rivális anekdota üssön rést, viszszavezetve az alapértelmezettnek tartott bizonytalansághoz.

Az újhistorikus az egyik kezével ad, amikor olyan szálat húz ki és mutat meg az események és összefüggések nyersanyagául szolgáló ágensek (emberek, állatok, tárgyak, intézmények, mentális objektumok) Nagy Összegabalyodásából, amelyet korábban nem vagy nem így húzott kis senki sem, de a másik kezével elvesz, mert az összegabalyodásban jelen lévő többi hatástényezőt nem vagy nem súlyának megfelelően veszi figyelembe, emiatt levezetése óhatatlanul hiányos lesz. De azzal, hogy a narrációk középpontjába állított tevékeny szubjektum nem tünik el a struktúra mögött, hanem elvárásai, tervei és cselekvései aktívan alakítják a világot, az újhistorikus kánonban az énformálás (self-fashioning) a társadalmi változás motorjaként mutatható be. „Minden cselekvés egy stratégia részét képezi, ezáltal az elszigetelt gesztus vagy gondolat is olyan kollektív, társadalmi energiával rendelkezhet, ami változást indít el a dolgok rendjében." (Lábadi, 2002) Az ,aktív alakítás” tézise azonban a cselekvő ember mellett ugyanúgy igaz az „összefonódások” világának ideális objektumaira, a dolgokra, a teljes nonhumán szférára is.

S mivel korábban jellemzően csak járulékosan rendeződtek olykor-olykor embereket középpontba helyező elemzésekbe tárgyak, mint díszek a karácsonyfára, a tárgyak köré épített narrációk behatolással kecsegtetnek releváns jelentés- és hatáskapcsolatok új világaiba. Így vált emblematikussá Stephen Greenblatt minikrónikája Wolsey püspök vörös posztósüvegének a 16. században induló viszontagságairól, amelynek során végül egy vándor színjátszó csoporttól került a 18. században Oxford egyik templomába. De említhetnénk Théophile Gautier-nek egy korszak jelképévé vált vörös mellényét az Hernani bemutatójáról, 
vagy azokat az újhistorikus áthallásokat és rokonságot sokszor nem is reflektáló „klasszikusabb veretü” történeti munkákat, amelyek Hammurapi cipője (Cline, 2014) vagy Vermeer kalapja (Brook, 2009) mellől indulva füzik fel egymás mellé hajdanvolt összegabalyodások izgalmas darabkáit.

Mindezt immár Hankiss mikroverzumával ütköztetve egyszer csak elénk sodródik a Napkirály arany fürdőkádja, amelynek peremén a Ma hétköznapiságának egykori kivételessége csillog. A mosógép, amely a mulandóság legyőzésének fehér hírnöke. A ház, a kert, az automobil, a cipő, a fogkrém, a borospohár, meg persze megszámlálhatatlan mennyiségü állat, amelyek mind-mind hasonló üzeneteket hordoznak. Hankiss szótárában: a fizikai dzsungel világa. Amelynek minden egyes nonhumán darabkája esélyt kínál magasabb rendủ felismerések közvetítésére az emberi belvilág és a társas lét ősvadonjának feltérképezéséhez, $\mathrm{s}$ evvel egyúttal egy metafizikai dzsungelhez is utat nyit.

Mi mást kéne mindebben látnunk, mint a geertzi sürủ leírás sajátos alkalmazását? Amire Szabó Márton (2004) tolmácsolásában tekinthetünk úgy, mint „az az egész és a rész, a konkrét és az elvont, az egyedi és az általános egymásba való szüntelen átjátszásának megmutatása, [...] az elemzett »jelentésteli struktúra« minden vonásának minél teljesebb bemutatása”. Célja, hogy ,jelentős következtetéseket vonjunk le jelentéktelen, ám igen sủrü szövésủ tényekböl", igazodva ahhoz az összetettséghez, rendszerszerủ koegzisztenciához, amely a társadalmi lét különböző szféráinak együttmüködésében, összefonódásában, egymásra hatásában érhető tetten. Ám míg az újhistorikus kiindulópontja egyedi történeti helyek és korok egyedi textusai mögötti teljességek rekonstrukciója, addig Hankiss számára maga a kultúra egésze az egyetlen óriás szöveg, a társadalmi léttel összekapcsolt nooszféra, amelynek megértéséért sorompóba száll, elszakadva a tér és az idő kötöttségeitől. Ha az újhistorikusnak mindent, ami egy irodalmi vagy történeti forrásszöveg (esemény, történeti tény) jelentésszerkezetének feltárásához szükséges, számba kell vennie és össze kell tudnia illeszteni, Hankissnál ugyanez a teljesség körüljárásának imperatívusza. Ha van még egy megfontolás, szempontocska vagy nyitott kérdés, amelynek diskurzusba vonása nélkül valamit nem vettünk számításba, akkor azokat nem nélkülözhetjük. Mindenröl beszélni kell, mindennek jelentősége van, a határok képlékenyek, és a megkonstruálandó elemzések sokszor csak egymással tökéletesen szembenálló diskurzusformák egyidejű jelenlétével alkothatók meg (Lábadi, 2002). Hankiss, mint egy született újhistorikus, mesteri módon ugrál az állítások színe és visszája között, olykor úgy végtelenítve a logikai levezetéseket, ahogyan M. C. Escher képeit szemléljük. Ám míg a „törvény szövedékének” felhasításához az újhistorikusok a látszólag partikuláris történéseket vizsgáló és színre vivő reprezentatív anekdotákkal sodródnak közelebb, megragadva a történelmi társadalom szövetében megbúvó szimbolikus cselekvéseket (Kiss, 2006), addig Hankiss inkább kollázstechnikával él. Egymás mellé sodor anekdotákat, vándormotívumokat, közmondásokat, aforizmákat, 
irodalmi idézeteket, hogy a gondolkodás ily módon felduzzasztott terében saját módszerének készítse elő a talajt: a visszakérdezésnek és a problémák fraktálosításának, amellyel nem a semmibe, hanem nagyon is szilárd szárazföldekre vezeti magát és olvasóit. Újhistorikus módi, de annak kétségkívül renitens.

Olyasmit érünk tetten, ami több mint a puszta újhistorikus nézőpont, mint egy alternatív tudományos beszédmód. Amivel Hankiss tusakodik, az az, hogy miként lehet az összefüggések rendszerében való útkereséshez szilárd metodológiai támasztékokra lelni akkor, amikor a Nagy Elméletek magyarázó ereje egyre kevésbé segít megértéshez, mi pedig azt látjuk, hogy eközben mégis egyre csak szaporodnak a rivális Nagy Elméletek. Emiatt szükségszerűen megkérdőjeleződnek azok a kiindulópontok, elhatárolások és kategóriaképzések, amelyekből a korábbi Nagy Elméletek merítették az erejüket. Michael Callon, Bruno Latour és John Law cselekvőhálózat-elmélete, Gilles Deleuze assemblage-elmélete vagy a társadalomtudomány térbeli és nonhumán fordulata ilyen értelemben mutat túl a hagyományos diskurzusokon, és ezért is nehéz Hankiss civilizációelméleti munkáit „besorolni” bármilyen irányzathoz. De ha mégis valahová, akkor az legyen az újhistorizmus.

Külön érdekesség, hogy amikor még nem az egész kultúra, mint az emberiség Jurij Lotman-i értelemben vett információraktára, hanem annak csak egy kis darabkája, az irodalmi mủ állt Hankiss érdeklődésének középpontjában (Hankiss, 1985), már akkor is vérbeli újhistorikus módjára fordul a mikrodinamizmusok irányába, felismerve a síkváltásban rejlő erőt, ahogy egyetlen képbe sürítve több valóságdimenzió mozgósítható a hatás érdekében. Az oszcilláció, amit Hankiss a síkok közti váltogatásként azonosít, nem más, mint saját későbbi munkamódszere, amellyel ezt a kompozíciós technikát a költői nyelvből az értekező prózába viszi át. A nagy, integrált magyarázó szerkezetek helyett a többoldalú kölcsönös kauzalitások, a bonyolultabb összefüggésrendszerek aprólékos feltárásától remél jó kiindulópontokat. Minél komplexebb a vizsgált tárgy, minél jobban érdekel minket a struktúra és a funkció, annál fontosabb azok ágenseinek aprólékos azonosítása.

Nem állna azonban meg a lábán az „emberi kaland” újhistorikus óriáskompozíciója, ha nem stabilizálná három, rendkívül fontos mozzanat, amelyekre nem érvényesek a kérdőjelek. Az egyik az értelemkeresés és értelemadás fundamentumának tekintett kiinduló helyzet: az ember egy rideg és ellenséges (kozmikus) környezetben kultúrájával épít maga köré „burkot”. Korántsem szükségszerü azonban, hogy erre a tézisre épüljön ember- és civilizációkép, és sokan nem is innen indulnak el. Hankissnak ezt az arkhimédészi pontját azonban a magunk részéröl teljesen autentikusnak tartjuk. A másik az a latens szerkezetképzés, ahogyan a látszatra véletlenszerüen egymás mellé sodort elemek mögött mégis kitapintható egy háttérstruktúra: egy olyan rendszerszemlélet, amely még akkor sem feledkezik meg a komplexitásról, a rétegzettségről és a kölcsönös hatáskapcsolatokról, amikor ezen rendszerek legapróbb komponenseivel bíbelődik. 
S végül: Hankiss narrációja nem távolságtartó, és nem kerüli el a személyes viszony kialakítását saját gondolkodói pozíciójával. Minden töprengése, amely látszólag megáll az elbizonytalanításnál, relativizálásnál, dekonstrukciónál, valójában nagyon is tele van pozitív kifejtéssel, határozott állásfoglalással. S mivel ugyanúgy a reneszánsz és a kora újkor a történeti keret, amelyben a legjobban érzi magát, és ahonnan kiemelt szempontjai vétetnek, mint az újhistorikusoknál, humanizmusa is ide ágyazódik be, és innen szárnyal aztán egészen a kibertérig. S aki úgy érezné, hogy a kétségüzenetek számosabbak, vegye észre, hogy ez is csak egy elmetrükk. Mint Vörösmarty Mihály Az emberek címü versében, midőn addig ismételgeti, hogy nincsen remény, amíg az olvasó dühösen kimondja, hogy de van, úgy lesz sokkal nagyobb esélye annak, hogy Hankiss olvasója is hasonló utat jár végig. Értékválságtól hangos, fogódzókat kereső korunkban Az emberi kaland és $A$ befejezetlen ember emiatt (is) maradhat még sokáig a házikönyvtárak népszerü darabja.

\section{IRODALOM}

Brook, T. (2009): Vermeer's Hat: The Seventeenth Century and the Dawn of the Global World. London: Bloomsbury Press

Cline, E. H. (2014): 1177 B.C.: The Year Civilization Collapsed. Princeton: Princeton University Press

Dobos I. (2001): A szöveg történetisége - a történelem textualitása: Az újhistorizmus. Irodalomtörténet, 32, 4, 594-610. http://epa.oszk.hu/02500/02518/00294/pdf/EPA02518_irodalomtortenet_2001_04_594-610.pdf

Greenblatt, S. (2015): Egy reneszánsz könyvvadász: Hogyan vált modernné a világunk? Budapest: Typotex Kiadó

Hankiss E. (1985): Az irodalmi mü mint komplex modell. Budapest: Magvető Kiadó

Hankiss E. (1997): Az emberi kaland. Budapest: Helikon Kiadó

Hankiss E. (2014): A befejezetlen ember. Budapest: Helikon Kiadó

Kiss G. Z. (2006): Különleges örömmel. Jelenkor, 49, 9, 928-932. http://www.jelenkor.net/ userfiles/archivum/2006-9.pdf

Koch S. - Juhász-Nagy P. - Lábos E. - Szathmáry E. (1989): A tökéletlenség és korlátosság dicsérete. Budapest: Gondolat Kiadó

Lábadi Zs. (2002): Csodálkozás és rezonancia: Stephen Greenblatt. http://www.zetna.org/zek/folyoiratok/65/labadi.html

Petroski, H. (1982): To Engineer is Human. New York: Vintage Books

Petroski, H. (1994): The Evolution of Useful Things. New York: Vintage Books

Petroski, H. (2008): The Toothpick: Technology and Culture. New York: Vintage Books

Szabó M. (2004): A diszkurzív politikatudomány alapjai. Budapest: L'Harmattan Kiadó, http:// www.tankonyvtar.hu/hu/tartalom/tkt/diszkurziv/ch04s02.html 